なわち指紋）は遺伝要因と環境要因の複 雑な組み合わせによって決まるため、一 卵性双生児の間でさえ異なる。そして、 損傷を受けた場合を除き、指紋は生涯に わたり不変だ。皮膚には自然な油分があ るため、ほとんどどんな表面にも指先が 触れると指紋が残る。

指紋鑑定法への懸念は、現場で発見 された指紋が鑑定官のもとに届けられ た時点から始まる。鑑定官の多くは専 門的訓練を長年受けているので、さほど 問題はない。問題は、ほとんどの国で採 用されている ACE-V 法という指紋鑑定 法にある (下図参照)。ACE-V の名は、 analysis（分析）、comparison（比較）、 evaluation（評価）、verification（確認） の 4 つの段階の頭文字をとつたものだ。 $\mathrm{ACE}$ と V の間にハイフンが入っている のは、第四段階の確認は、最初の三段階 とは別の鑑定官が、同じプロセスを繰り 返して行うことを表している。

分析は全体的な特徵を見ることから始
まる。指紋には渦状紋、蹄状紋、弓状 紋という 3 つの主要なパターンがあり、 指紋を分類したり、容疑者を速やかに除 外したりするのに使える。次に、隆線の 終止や分岐など、細かい特徴を見る (図 参照)。これにより、高度な個人識別が 可能になる。

指紋の特徵を明らかにしたら、次に比 較を行う。その指紋とサンプル指紋（捜 査ファイルから探し出した指紋や容疑者 から採取した指紋）との類似点や相違点 をチェックするのだ。このプロセスは 自動化が進んでいる。1980 年代には自 動指紋識別システム (AFIS) が開発され、 1990 年代にはデジタル指紋取り込み技 術が開発された。今日の AFIS 技術では、 FBI などが収集した膨大な指紋データ ベースを走査し、自動的にふるい落とし、 数個の候補だけを表示する。あとは、鑑 定官が目で見て一致する指紋を選び出す わけだ。

ACE-V 法のプロトコルによると、第
三の段階である評価により、鑑定官は 3 つの結論のいずれかに至る。すなわち、 その指紋とサンプル指紋が同一の指のも のだと考えられる「一致」、污れなどに より説明することのできない著しい相違 点が少なくとも 1 か所あるため、同一 の指の指紋とは考えられない「除外」、 および、指紋が不鮮明のため、鑑定官が 確信をもつて判定できない「判定不能」 の 3 つである。

カリフォルニア大学ロサンゼルス校の 法学者 Jennifer Mnookin は、この鑑定 法は「偽陰性」が出るよう意図的に作ら れている、と指摘する。つまり、1 か所 でも相違点があれば除外となるし、どん なに多くの類似点があっても判定不能と される場合がある。これは、犯罪者を特 定しそこなうリスクよりも、無実の人に 罪を着せてしまうリスクのほうを重大視 するからである。

しかし、Mayfield 事件をみればわか るように、それでも偽陽性は出てしまう。
指紋のパターンと ACE-V 法

ほとんどの指紋は、渦状紋、蹄状紋、弓状紋という３つのグループに入る。隆線を細 かく調べていくと、分岐、鉤、橋、島などの小さな特徵がたくさん見つかる。通常、指 紋 1 個につき細かい特徴が 150 個あり、その正確な配置に基づいて指紋を同定 することができる。

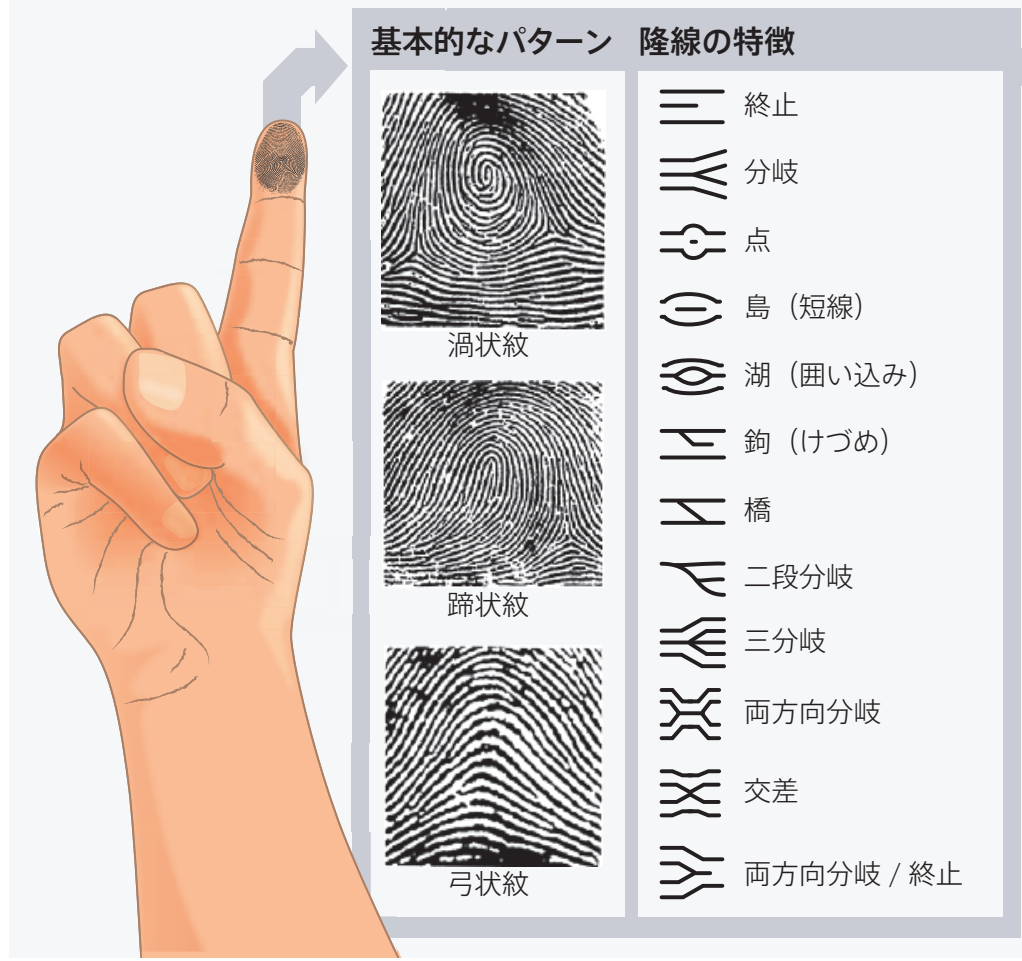

\section{ACE-V 法のプロトコル}

1.分析

犯罪現場に残された指 紋の特徵を鑑定官が分 析する。

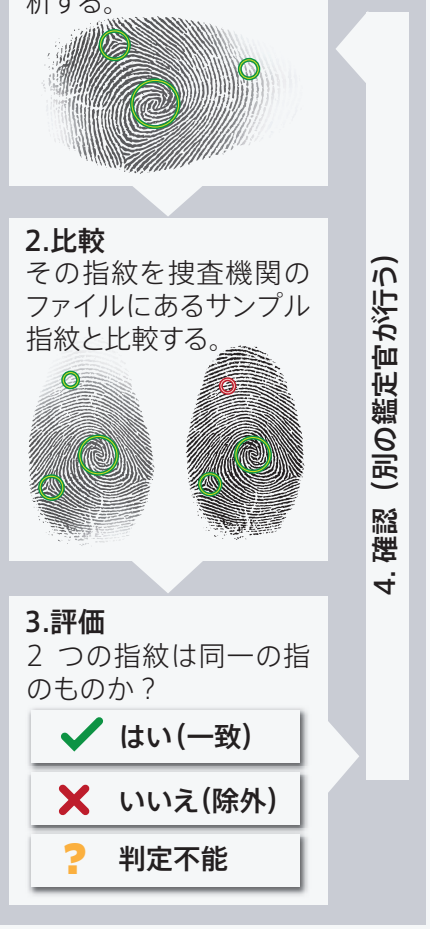


最も重大な問題は、「そもそもなぜこう したミスが起こるのか」ということだ。

ACE-V 法の問題の 1 つは、プロトコ ルが厳密に実施されていない点にある。 例えば、分析と比較は分けて行うことに なっており、鑑定官はまず指紋を詳細に 分析して特徴を明らかにした後で、サン プル指紋を見ることになっている。分析 しながら比較すると、分析だけしていた ときには目につかなかった特徵を「発見」 してしまい、循環論法に陥る危険性があ るからだ。

ところが実際には、分析と比較は常 に分けて実施されているわけではない、 と法科学コンサルタントの Lyn Haber はいう。2009年に夫である心理学者 の Ralph Haber と『Challenges to Fingerprints（指紋証拠への異議）』を 共同執筆した彼女は、多くの指紋鑑定官 が、時間を節約するために、分析と比較 を同時に行っていると指摘する。FBI は、 この慣行が Mayfield 事件のミスの一因 となったと強調した。

\section{先入観の影響}

もう 1 つの問題は、ACE-V 法のプロト コルそのものが、少なくとも学問的基準 からすると厳密ではないことだ。例えば 最後の確認は、最初の分析と「独立」に 行うよう求めているが、厳格なガイドラ インを定めていない。そのため、確認を 行う鑑定官は分析を行った鑑定官と同じ 部署で仕事をしており、自分が誰の鑑定 結果をチェックしているのか知っている ことが多いのだ。

ACE-V 法は、鑑定官が自分の鑑定し ている指紋について何を知ることがで き、何を知ることができないかについて も、特に厳しく定めていない。2006 年に

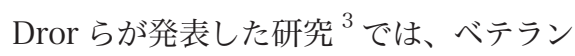
鑑定官も新人も、関連情報を与えられる と判定が摇らいでしまうことを示した。

ある実験では、6人の鑑定官に指紋を 鑑定させた。実は、その指紋は鑑定官た ちが以前に鑑定したものなのだが、その 事実は告げないでおく。そして、今回の
鑑定では、鑑定官にあらかじめ、容疑者 は既に自白しているとか、犯行時には警 察に留置されていたなど、事件に関連す る情報を与えた。その結果、実に $17 \%$ の判定が、与えた情報に沿つた方向へと 変わってしまったのだ。去年の NAS 報 告書ではこの点が強調され、「ACE- $\mathrm{V}$ 法 は先入観が入り込むのを防ぐことができ ず、再現性と透明性を確保することがで きない。同じ手法で鑑定を行う 2 人の 鑑定官が同じ結果を得る保証はない」と された。

\section{指紋鑑定官は専門家か?}

指紋鑑定を批判する人々の中には、鑑定 官の技能を疑問視する人もいる。Haber 夫妻が著書で指摘したように、多くの場 合、犯罪の真相は不明なまま終わるため、 鑑定官が自分の判断が正しかったかどう かを知ることはめつたにない。その結果、 「どんなに長く経験を積んでも、鑑定の 精度は向上しない可能性がある」のだ。

指紋鑑定官の一部は、こうした批判を 真つ向から否定する。英国指紋協会の Martin Leadbetter 会長は、2007 年の 会誌 $^{4}$ に、外部からの情報で判断がゆら ぐような無能な鑑定官は「ディズニーラ ンドで仕事を探すべきだ」と書いた。

しかし、批判を䈯摰に受け止める鑑 定官もいる。英国で最大規模のグレー ターマンチエスター警察の法科学鑑定部 の Kevin Kershaw 部長は、先入観に関 する Dror の研究について知ると、捜査 官が鑑定結果を待つために法科学部を訪 れることを禁止した。捜査官が鑑定官に 事件に関する話をするのを防ぎ、鑑定官 に先入観をもたせないようにするためだ (彼はそれ以外の改善も進めている)。

ローザンヌ大学 (スイス) の法科 学鑑定の専門家である Christophe Champod は、指紋鑑定官が鑑定結果を 「一致」「除外」「判定不能」としか表 現できない現在のシステムは、指紋鑑定 の不確実性を法廷から隠している、と考 える。そして、他の法科学的証拠と同様、 指紋証拠も確率的に解釈して、鑑定官が
一致の可能性について自由に語れるよう にすべきだと提案する。例えば「被告人 がその指紋を残したとしたら一致の見込 みは 95\%であり、ほかの人物がその指 紋を残したとしたら一致の見込みは 10 億分の 1 である」といった形で証言で きるように、だ。

しかし、そうするには、集団によって 指紋のパターンがどのように異なってい るか、あるいは、指紋のさまざまな要素 や、要素の組み合わせがどのような頻度 で現れるかなど、基本的情報が必要だ。 この種の研究はいくつか行われているも のの、規模は十分に大きくはなく、系 統だってもいない。それでも Champod は、指紋の確率的解釈に対して楽観的だ。 DNA などとは違い、指紋のパターンは 集団間でほとんど変化がないので、調査 は容易なはずだからだ。指紋証拠を確率 的に解釈するシステムは、鑑定プロセス の透明性を高めることにつながる。

指紋証拠にどの程度の重みを与える か、最終的に決定するのは法廷だ。法廷 がなお指紋を絶対的な証拠として扱い、 たつた 1 個の指紋が有罪証拠として人 を刑務所送りにする現状を、Mnookin は「悲惨な法学」とよぶ。Champodも 「指紋証拠は単なる補強証拠として扱わ れるべきです」という。でも裁判官はま だ、現状を変える意欲はみせていない。

コロンビア特別区巡回裁判所の首席判 事で、去年の NAS の報告書を作成した 委員会の共同議長である Harry Edwards は、法科学コミュニティーは、科学的文 化を取り入れる必要があるという。「道 のりは遠そうではありますが」。

(翻訳 : 三枝小夜子、要約 : 編集部)

Laura Spinney は、スイスのローザンヌに拠点を置 くフリーランスのライター。

1. A Review of the FBI's Handling of the Brandon Mayfield Case (Office of the Inspector General Oversight and Review Division, 2006).

2. Strengthening Forensic Science in the United States: A Path Forward (National Academies, 2009).

3 Dror, I.E. \& Charlton, D. J. Forensic/dentification 56, 600-616 (2006).

4. Leadbetter, M. Fingerprint Whorld 33, 231 (2007).

www.nature.com/scienceincourt も参照されたい。 